\title{
A Supplier Selection Model Emphasizing the Project Risk Management in Drug Production in Pharmaceutical Industry
}

\author{
Malek Mohammad Sabbaghi, Ahmad Allahyari
}

\begin{abstract}
Risk management is considered to be one of the main phases of project management and one of the eight main areas of the "project management body of knowledge". The complexities involved in the drug production projects on the one hand, and the need for risk assessment and management in such projects on the other hand, make this issue completely clear. According to the risk mitigation strategies in project management and using the academic professors and experts in the field of drug production and pharmaceutical projects, the present study aimed to provide a checklist for selecting supplier in the drug production projects. This was done using the main eight and 30 secondary indicators related to the top supplier selection and four main and nine secondary indicators related to influencing environmental risks. Finally, after reviewing the statistical results obtained from the questionnaires and utilizing the TOPSIS technique, seven main indicators including "quality, flexibility, delivery, technology, information and communication systems, cost and experience" along with 24 secondary indicators were obtained relating to the top supplier selection. Also, the delivery factors group was identified as the most important group based on the Friedman test results.
\end{abstract}

Keywords: Assessment Model; Pharmaceutical Industry; Project Management; Project Risk; Supplier Selection

\section{INTRODUCTION}

The pharmaceutical industry is defined as a combination of processes, operations and organizations involved in discovery, creation and production of drugs. According to the diversity in the pharmaceutical industry, the present study is mainly focused on the supplier selection and the factors affecting the supplier selection in the drug production projects so as to mitigate the risk involved in this regard. As organizations always try to improve their market share, increase profit and achieve the competitive advantage, they need to consider the project management principles and standard steps toward it. Organizations in the 1960s and 1970s were always trying to increase the competitive power by standardizing and improving processes towards their customers. These efforts were continued in the 1990s by developing the project management methods considering the strategic suppliers and logistic operations [1].

In recent years, by increasing the supplier organization outside the main organization, the outsourcing organizations have been facing the variety of options when selecting the source of supply. Along with this issue, increasing the commercial competition in global markets has caused organizations to pay more attention to optimizing their processes in all competitive aspects including the supplier selection. The decision makers in the field of outsourcing try to select the alternative among the available suppliers which can meet all of the outsourced process needs in the best possible way [2].

\subsection{Problem Statement and Research Background}

Organizations in the 1960s and 1970s were always trying to increase the competitive power by standardizing and improving their internal processes in order to produce a more qualified and cost-effective product. They mainly believed that a robust engineering and design together with the integrated and coordinated operations are the prerequisites of achieving the market demands and as a result, increasing their market share [3]. Hence, the organizations were mainly focused on increasing their flexibility.

By increasing the customers' expectations in the 1980s, organizations increasingly became interested in improving flexibility in the production lines and developing new products to meet the customers' needs. Along with improving production processes in the 1990s, and well as utilizing the reengineering methods, managers of many industries found that it was no longer enough to improve the internal processes and flexibility and that they needed to cooperate with the best part and material suppliers who produced with the best quality and at the lowest cost. In addition, the distributors needed to have close relationships with the manufacturer's market development policies. Tab. 1 shows some research related to the present study.

Table 1 Research Related to the Present Study

\begin{tabular}{|l|c|l|}
\hline \multicolumn{1}{|c|}{ Title } & Method & Researcher /year \\
\hline $\begin{array}{l}\text { Identifying and prioritizing the } \\
\text { project risk based on PMBOK } \\
\text { with fuzzy approach [4] }\end{array}$ & $\begin{array}{c}\text { AHP, } \\
\text { TOPSIS }\end{array}$ & Olfat et al., 2010 \\
\hline $\begin{array}{l}\text { Project Risk assessment and } \\
\text { management using value } \\
\text { engineering approach [5] }\end{array}$ & $\begin{array}{c}\text { Value } \\
\text { engineering } \\
\text { approach }\end{array}$ & Alem Tabriz et al., 2014 \\
\hline $\begin{array}{l}\text { The project risk deployment } \\
\text { model based on EFQM [6] }\end{array}$ & EFQM & Amiri et al., 2014 \\
\hline $\begin{array}{l}\text { Project risk management } \\
\text { assessment in mass production } \\
\text { projects [7] }\end{array}$ & MADM & Bani Asadi ez al., 2005 \\
\hline $\begin{array}{l}\text { Tunnel building projects risk } \\
\text { management [8] }\end{array}$ & $\begin{array}{c}\text { TOPSIS, } \\
\text { SAW, LA }\end{array}$ & Sayadi et al., 2011 \\
\hline
\end{tabular}

Olfat et al. (2010) identified and prioritized the project risk based on PMBOK standard with fuzzy approach in the interchange building project in the Boushehr Province [4]. According to their research results, the accidents are among the most important risks in the interchange building projects in Boushehr Province that can be dramatically mitigated by utilizing the location principles. Alem Tabriz [5] also 
assessed and managed the project risk by value engineering approach with the aim of utilizing the value engineering techniques in the civil projects risks management so as to improve the project value and mitigate the probable risks. In their research, they calculated the project value index in the case of implementing reactive measures to the projects risks and assessing the costs of these measures after implementing the risk management work plan based on the PMBOK standard and improving the plan in case of decreasing trend of this index through the international standard of value engineering technique (SAVE). According to their findings, utilizing this framework in the Tehran subways project can cause mitigating and dealing project risks to save 49.6 percent in the projects costs after implementing the value engineering technique on the reactive measures facing the most critical project risk and improving the project value index from -3.2 to -1.6. Bani Asad et al. in 2005 have identified and prioritized the civil project risks in Mehr Housing Project using the MADM technique in Iran [7]. Sayadi in 2011 studied the Tunnel building risk management. They evaluated and ranked a relatively complete set of criteria to use in MADM techniques relating the Tunnel building projects in Seymare Dam in the south west of Iran. Also, the experts' views were gathered using the group decision making techniques and the linear allocation methods. Similarity to the ideal solution and the simple weighted set were used to determine the risk ranks. The risks resulted from the economic factors and commitments/ guarantees have the most and the least ranks, respectively [8].

Table 2 Risks involved in production projects management

\begin{tabular}{|l|l|}
\hline \multicolumn{1}{|c|}{ Risk } & \multicolumn{1}{|c|}{ Definition } \\
\hline financial & Change in exchange rate \\
\hline transit time & $\begin{array}{l}\text { Change in the transit time including the transportation and } \\
\text { clearance }\end{array}$ \\
\hline forecast & $\begin{array}{l}\text { Errors in needs estimation that resulted in over or under- } \\
\text { estimated inventory }\end{array}$ \\
\hline Quality & $\begin{array}{l}\text { Damaged, unfinished and different products, parts or } \\
\text { material in different areas }\end{array}$ \\
\hline Safety & The products that endanger safety \\
\hline $\begin{array}{l}\text { Disruption in } \\
\text { business }\end{array}$ & Inability to produce or selling the product to customers \\
\hline Survival & Factory bankruptcy \\
\hline $\begin{array}{l}\text { Tools and } \\
\text { inventory } \\
\text { ownership }\end{array}$ & $\begin{array}{l}\text { Disagreement about the inventory ownership, overuse of a } \\
\text { vehicle owned by others }\end{array}$ \\
\hline culture & $\begin{array}{l}\text { Insufficient information about people, culture and } \\
\text { language }\end{array}$ \\
\hline Opportunism & The supplier's opportunistic behavior with customer \\
\hline Oil price & Change in oil price \\
\hline
\end{tabular}

The Project Risk. Sitkin and Pablo (1992) defined the risk as the "range where uncertainty exists about whether it is fulfilled as the potentially successful or disappointing outcomes" [9]. The measures that probably produce the profitable effects mostly include risks. Richi and Brandly also defined the business risks as follows: the level of dealing with the uncertainties that the company should understand and manage when implementing its strategies to effectively achieve business goals [13]. Tab. 2 presents the common risks in managing the production projects including the pharmaceutical projects.
Christopher (2004) classified the risks involved in the production projects in five classes of supply risks, process risks, demand risks, control risks, and environmental risks [911]:

Risk of supplying raw materials: one of the most important risks in production that can result from other risks. When we pay for a product or service while the service provider may not meet it with good quality or in time, we face this king of risks which is called the supply risk.

Process risk: when the product is not produced in timely manner or with the needed quantity or quality.

Demand risk: risk resulting from lack or shortage of demand for a special product.

Control risk: resulting from the insufficient quality control.

Environmental risk: the risk of the environmental effects that can result from the physical, social, political, legal, operational and economic environment. The pharmaceutical market is regulated according to the demand and supply nature in many countries. Considering the competitiveness of the pharmaceutical market, governments should balance between economical and healthcare benefits [9]. The pharmaceutical sector plays an important role in the medical and healthcare system. Due to the increasing population and aging, economic growth and epidemic disease (such as cardiovascular disease, and respiratory chronic cancers and disease), the pharmaceutical industry is increasingly growing [12-14].

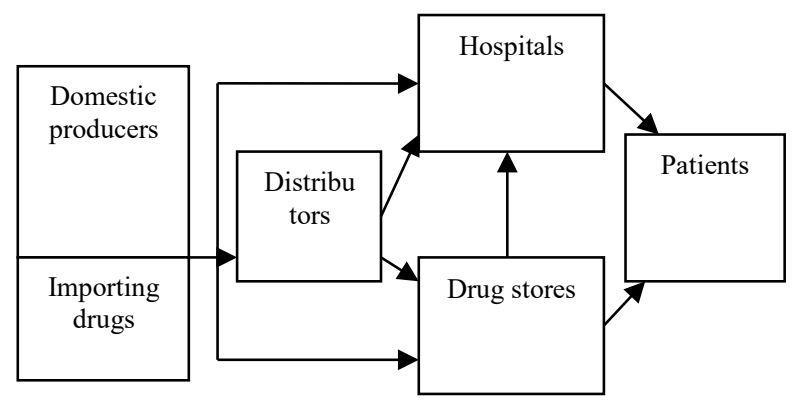

Figure 1 Pharmaceutical industry producers and customers

These are some problems when transition from an planned economy to a powerful company in the pharmaceutical industry:

The ineffective and resultless monitoring [16].

Higher price for a drug means the higher profit for producers [17].

Violation and pricing disproportionately to the preferential prices [18].

Lack of an authorized drug guidance $[19,20]$.

\subsection{Risk Management in Project Management}

The term risk, as defined in the PMBOK project management standard $6^{\text {th }}$ version by the PMI institute, has a negative meaning in Persian - it refers to uncertain events in future in project management that can result in an opportunity or threat. 
Opportunities or threats can result in some problems if they are ignored while they can be solved with a low cost and turn to valuable opportunities. Hence, the measures that should be taken to deal with them are called risk management.

Risk management is inevitable and it also exists in unorganized projects in an unsystematic and intuitive manner. The point is to achieve the most positive results from the risk management by making it a systematic activity.

According to the PMBOK standard in this regard, the risk management approach should be first determined. Then, risks should be identified and after analysis, the most important one should be selected. Subsequently, the activities to control the important risks and incorporate the obtained results in other plans such as time and cost should be determined. Finally, the results should be evaluated to take necessary actions in case of deviation [21].

Risk management is initiated with managerial planning in the PMBOK standard. Like other managerial plans, risk management plan determines the measures that should be taken in this regard. In addition to methodology, the roles and responsibilities related to risk and the parameters used in future to identify and analyze risk should be determined. After the risk management planning process, risks should be identified in the proper time and with proper tools and consider a hierarchical structure for them which is called the Risk Breakdown Structure (RBS).

After identifying risks based on the PMBOK standard, they should be analyzed from two aspects: quantitative and qualitative. The goal of Qualitative Risk Analysis is to select important risks to plan the proper responses to risk.

After determining the important risks using quantitative and qualitative analyses, they should be planned based on the PMBOK standard during the Risk Management Plan process. After knowing that an event will possibly occur in the future and in that case, has a significant impact on the project, we should think about our response to it. The answer to this question determines the response to the risk.

\section{Global Environment}

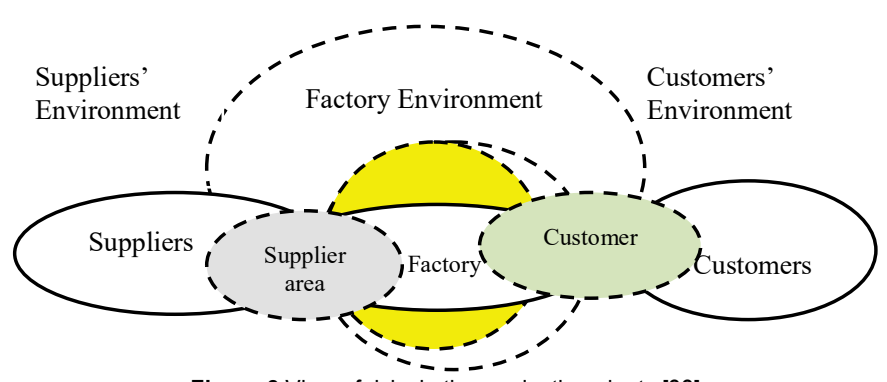

Figure 2 View of risks in the production plants [22]

Tab. 3 shows the risks identified in different stages of production process by different researchers [23].

According to the factors mentioned in different classifications by researchers, the sources of uncertainty have different effects on the organizational decisions.

If the organizational decisions are divided into three different types - operational, tactical and strategic - the interest rate has no effect on strategic decisions, while it has significant effect on operational decisions and a moderate effect on tactical decisions. The other uncertainty sources can also be divided as follows (Tab. 4).

Table 3 The risks identified by different researchers [24]

\begin{tabular}{|c|c|}
\hline Identified risks & Researcher \\
\hline Supplier market risk & Cooke \\
\hline $\begin{array}{l}\text { Quality, delivery, cost, capacity and production } \\
\text { tool, technical ability, economical status, } \\
\text { management and organization, performance } \\
\text { record, guarantees }\end{array}$ & Dikson \\
\hline $\begin{array}{l}\text { Communication systems, performance controls } \\
\text { and workers relationships, information shortage } \\
\text { and personal abilities in management and adopting } \\
\text { novel procedures }\end{array}$ & Gooley \\
\hline $\begin{array}{l}\text { Shutting down the transit routes such as docks, } \\
\text { conflicts between the management and workers' } \\
\text { groups }\end{array}$ & Machalaba and Kim \\
\hline Natural and unusual events & $\begin{array}{l}\text { Mitroff and } \\
\text { Alpalsan }\end{array}$ \\
\hline $\begin{array}{l}\text { The conflicts between the workers' laws and } \\
\text { commercial policies, different cultures and } \\
\text { complex managerial structures between the buyer } \\
\text { and supplier }\end{array}$ & $\begin{array}{l}\text { Seaman and } \\
\text { Stodghill }\end{array}$ \\
\hline Terrorism, cyber hackers and natural disasters & Simpson \\
\hline Natural disasters and technological failures & Stafford et al. \\
\hline Natural disasters such as flood, earthquake, etc. & Terhune \\
\hline Price, inventory, technology and quality & $\begin{array}{l}\text { Treleven and } \\
\text { Schweikhart }\end{array}$ \\
\hline $\begin{array}{l}\text { Market changes, products, technology, competitors } \\
\text { and governmental regulations }\end{array}$ & $\begin{array}{c}\text { Van der Vorst and } \\
\text { Heulens }\end{array}$ \\
\hline Suppliers communication and integration & Wanger \\
\hline $\begin{array}{l}\text { Capacity constraints, time cycle, disasters, } \\
\text { suppliers economical and commercial health, } \\
\text { managerial views, increased market price, } \\
\text { incomplete information systems and system design } \\
\text { changes }\end{array}$ & Zsidin \\
\hline
\end{tabular}

Table 4 The effect of uncertainty on the organizational decisions [25]

\begin{tabular}{|c|c|c|c|}
\hline $\begin{array}{l}\text { Uncertainty } \\
\text { sources }\end{array}$ & $\begin{array}{c}\text { Operational } \\
\text { decisions }\end{array}$ & $\begin{array}{c}\text { Tactical } \\
\text { decisions }\end{array}$ & $\begin{array}{l}\text { Strategic } \\
\text { decisions }\end{array}$ \\
\hline Interest rate & High effect & $\begin{array}{c}\text { Moderate } \\
\text { effect }\end{array}$ & -- \\
\hline $\begin{array}{c}\text { Supplier } \\
\text { delivery time }\end{array}$ & Low effect & High effect & Low effect \\
\hline $\begin{array}{c}\text { Supplier } \\
\text { quality }\end{array}$ & Moderate effect & Low effect & --- \\
\hline $\begin{array}{c}\text { Transportation } \\
\text { time }\end{array}$ & Moderate effect & $\begin{array}{c}\text { Moderate } \\
\text { effect }\end{array}$ & Low effect \\
\hline Random costs & Low effect & High effect & $\begin{array}{c}\text { Moderate } \\
\text { effect }\end{array}$ \\
\hline $\begin{array}{c}\text { Political } \\
\text { environment }\end{array}$ & -- & -- & $\begin{array}{c}\text { Moderate } \\
\text { effect }\end{array}$ \\
\hline $\begin{array}{l}\text { Available } \\
\text { capacity }\end{array}$ & Moderate effect & $\begin{array}{c}\text { Moderate } \\
\text { effect }\end{array}$ & Low effect \\
\hline $\begin{array}{l}\text { Random } \\
\text { demand }\end{array}$ & Low effect & High effect & $\begin{array}{c}\text { Moderate } \\
\text { effect }\end{array}$ \\
\hline $\begin{array}{l}\text { Delay in } \\
\text { information } \\
\text { access }\end{array}$ & High effect & $\begin{array}{l}\text { Moderate } \\
\text { effect }\end{array}$ & --- \\
\hline $\begin{array}{c}\text { Price } \\
\text { fluctuations }\end{array}$ & Low effect & High effect & Low effect \\
\hline
\end{tabular}

The Fault Tree Analysis (FTA) and Event Tree Analysis (ETA) are considered as two common techniques to study and search for factors and causes contributing to accidental events. Both make logical diagrams to display the faults that distribute through a complex system. FTA investigates all the 
potential events that resulted in critical events and it is a graphical diagram that shows how system stops [26, 27]. The analysis starts with critical events and then, the essential and sufficiently risky events are identified along with their causes and factors affecting their logical relations using the backward logic. The event tree diagram of the supplier's undesirable performance and its outcomes according to the Brindley and Ritchie paper is displayed in the following figure.

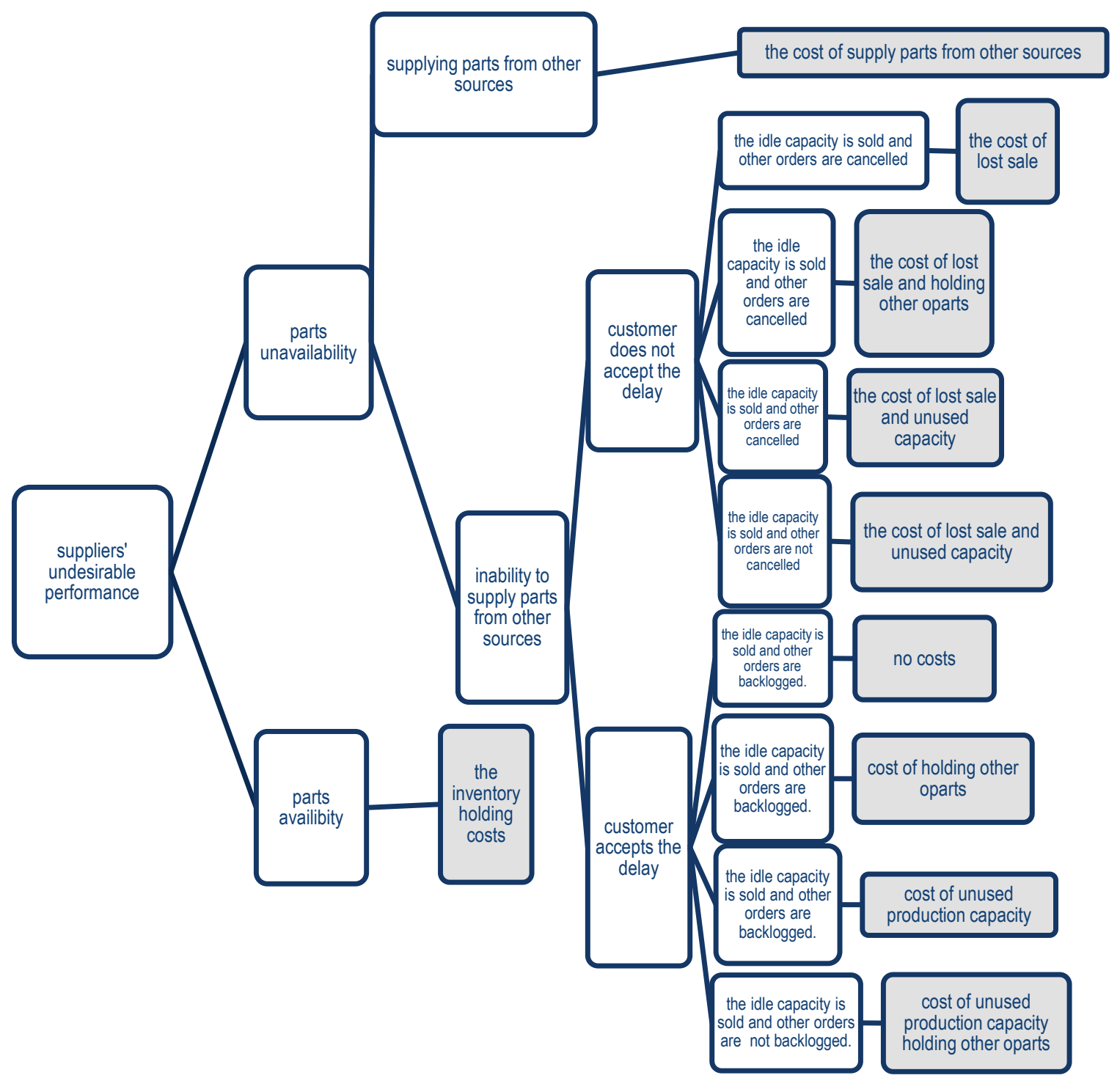

Figure 3 The Fault Tree Diagram of the supplier's undesirable performance and its outcomes

\section{RESEARCH METHOD}

The present study is an applied and developmental research since it seeks to select a supplier selection model emphasizing risk management in the country's pharmaceutical industry. It is also a descriptive research in tem of the method and a correlational research. In this study, all four areas of "supply, process, demand and environment" should be investigated in terms of the risks in order to identify and assess them and implement the necessary measures to manage them.

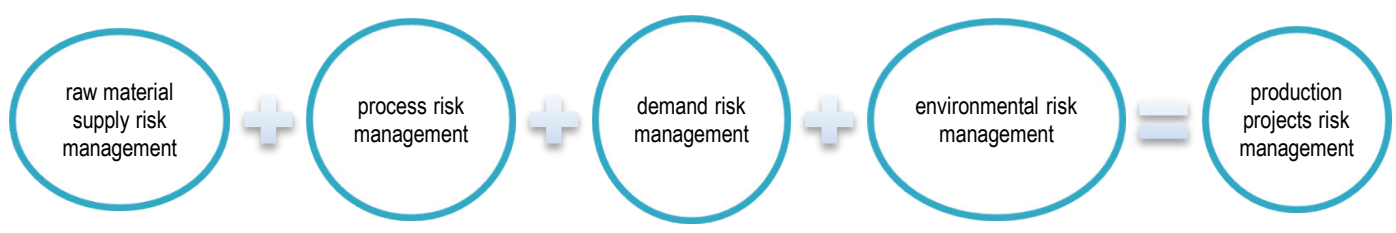

Figure 4 Four areas of risk management in the production projects 
According to the research literature and subject, risk management is followed in the "pharmaceutical production projects" and along with it, the environmental risks is also considered considering that they affect all three parts of supply chain including "supply risk".

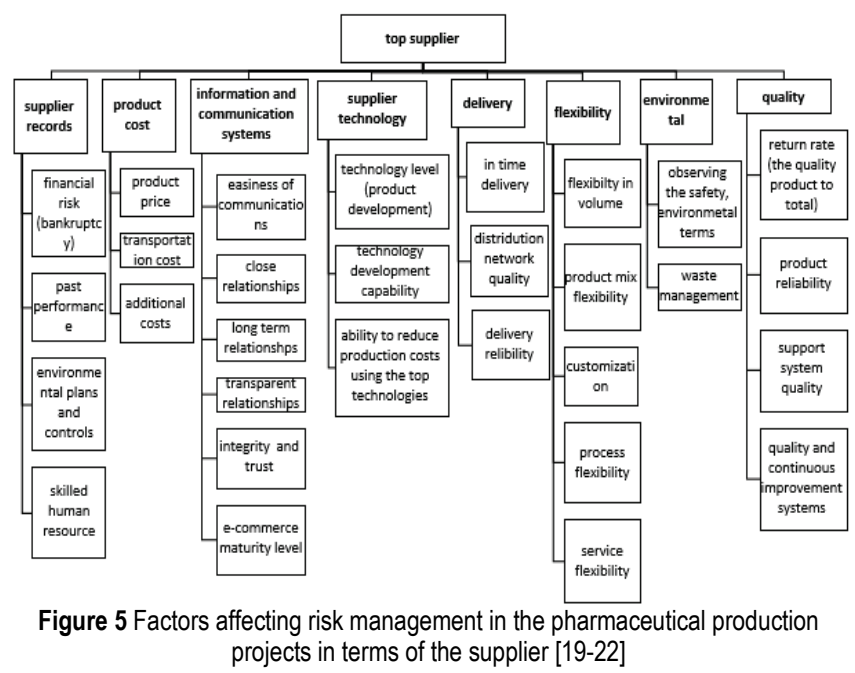

The country's pharmaceutical industry is considered in this study as the statistical population. Three large holdings including the Tamin pharmaceutical investment, Alborz investment and Shafadarou Company were also selected as the samples and the data obtained from them were evaluated. The reasons behind selecting these three holdings are:

There are four pharmaceutical producer holdings in the country that hold $75 \%$ of drug production share: Tamin pharmaceutical investment including Daroupakhsh and Pars Darou groups, Alborz investment, Shafadarou Company, and HITT. The first three were selected as the samples that hold $65 \%$ of the total pharmaceutical market share which is considered as a significant share of pharmaceutical industry. The share of each of these groups is as follows.

Table 5 The market share of the studied holdings
\begin{tabular}{|l|c|c|}
\hline \multicolumn{1}{|c|}{ Holding } & $\begin{array}{c}\text { Production } \\
\text { market share }\end{array}$ & $\begin{array}{c}\text { Distribution market } \\
\text { share }\end{array}$ \\
\hline Tamin pharmaceutical company & 22.90 & 30.65 \\
\hline Alborz & 15.86 & 21.47 \\
\hline Shafadarou & 6.55 & 8.91 \\
\hline
\end{tabular}

Table 6 The research main variables classification

\begin{tabular}{|c|c|c|c|}
\hline & Variable name & Type & Role \\
\hline \multirow{8}{*}{$\begin{array}{l}\text { The factors } \\
\text { affecting the } \\
\text { supplier risk }\end{array}$} & Quality & rank & independent \\
\hline & Environmental terms & rank & independent \\
\hline & Flexibility & rank & independent \\
\hline & Delivery & rank & independent \\
\hline & Supplier technology & rank & independent \\
\hline & $\begin{array}{c}\text { Information and } \\
\text { communication systems }\end{array}$ & rank & independent \\
\hline & Product cost & rank & independent \\
\hline & Supplier experience & rank & independent \\
\hline \multirow{4}{*}{$\begin{array}{l}\text { The factors } \\
\text { affecting the } \\
\text { environmental risk }\end{array}$} & Economic issues & rank & independent \\
\hline & Political issues & rank & independent \\
\hline & Cultural/social issues & rank & independent \\
\hline & Natural disasters & rank & independent \\
\hline
\end{tabular}

It should be noted that since the supplier companies do not operate separately and individually, and they are subsidiaries of the producing companies, then a separate market share is not considered for them. The available sampling with the purposeful/judgmental approach is used as the research sampling method. The research main variables are as can be seen in Tab. 6 . Since the validity and reliability are two main criteria for testing the measures accuracy and quality, [28], the content validity is used in this study to determine the validity. The professors and experts were asked regarding two options of the question relevance with the subject and its clarity. The reliability was also assessed by the Cronbach's Alpha coefficient as one of the most common tools for this purpose. As the scale with the Cronbach's Alpha coefficient higher than 0.7, it is reliable and the current scale is confirmed with the coefficient higher than $0.8[29,30]$. After modifications and verifying the questionnaire's validity and reliability, it is used as the data gathering tool.

Table 7 The Cronbach's Alpha coefficient among indicators

\begin{tabular}{|c|c|}
\hline No. of questions & Cronbach's Alpha coefficient \\
\hline 39 & .806 \\
\hline
\end{tabular}

Table 8 The Cronbach's Alpha coefficient among groups

\begin{tabular}{|c|c|}
\hline No of groups & Cronbach's Alpha coefficient \\
\hline 9 & .732 \\
\hline
\end{tabular}

The questionnaire was then distributed among mangers in supply, production, planning and logistics sectors. In case of non-availability of the managers in one sector, the questionnaire was filled by the informed expert (which occurred in less than $10 \%$ cases). Two questionnaires were removed due to the incomplete information and lack of answers for more than half of the questions. Finally, 62 questionnaires were analyzed. Questions on the respondents' education, experience, tenure and position were provided below. As can be seen, three respondents have a diploma, one has an associate degree, 27 respondents have a license, and 29 respondents have a master degree.

Table 9 Classification based on Education

\begin{tabular}{|l|c|c|}
\hline \multicolumn{1}{|c|}{ Education } & Frequency & \% of Frequency \\
\hline Diploma & 3 & 4.8 \\
\hline Associate degree & 1 & 1.6 \\
\hline Graduate & 27 & 43.5 \\
\hline Master and above & 29 & 46.8 \\
\hline Not answered & 2 & 3.2 \\
\hline Total & 62 & 100 \\
\hline
\end{tabular}

Table 10 Classification based on Experience

\begin{tabular}{|l|c|c|}
\hline \multicolumn{1}{|c|}{ Experience } & Frequency & \% of Frequency \\
\hline Lower than 1 year & 1 & 1.6 \\
\hline $1-5$ years & 10 & 16.1 \\
\hline 5-10 years & 16 & 25.8 \\
\hline More than 10 years & 31 & 50 \\
\hline Not answered & 4 & 6.5 \\
\hline Total & 62 & 100 \\
\hline
\end{tabular}


In terms of working experience, one, 10,16 and 31 respondents have 1 year, $1-5$ years, up to 10 years, and more than 10 years of experience, respectively.

In this section, in addition to the descriptive statistics results related to components, the One-Sample T Test was also used with the $95 \%$ confidence to examine the components' significance. The table below shows the related information.

Table 11 Descriptive statics related to quality

\begin{tabular}{|c|c|c|c|c|c|c|c|c|c|c|}
\hline \multicolumn{2}{|l|}{ Questions 1-5 } & $\begin{array}{l}\text { Very } \\
\text { low }\end{array}$ & Low & $\begin{array}{l}\text { Mode } \\
\text { Rate }\end{array}$ & High & $\begin{array}{l}\text { Very } \\
\text { high }\end{array}$ & SD & $T$ & sig & Result \\
\hline \multirow{2}{*}{$\begin{array}{l}\text { The high return rate of the products received from } \\
\text { the supplier }\end{array}$} & Freq & 0 & 0 & 4 & 30 & 28 & \multirow{2}{*}{0.6} & \multirow{2}{*}{17.9} & \multirow{2}{*}{0} & \multirow{2}{*}{ Confirmed } \\
\hline & freq $\%$ & 0 & 0 & 6.5 & 48.4 & 45.2 & & & & \\
\hline \multirow{2}{*}{ The good quality of the supplier support system } & Freq & 0 & 1 & 4 & 34 & 23 & \multirow{2}{*}{0.6} & \multirow{2}{*}{15.2} & \multirow{2}{*}{0} & \multirow{2}{*}{ Confirmed } \\
\hline & freq $\%$ & 0 & 1.6 & 6.5 & 54.8 & 37.1 & & & & \\
\hline \multirow{2}{*}{$\begin{array}{l}\text { The quality management and continuous } \\
\text { improvement systems in the supplier's factory }\end{array}$} & Freq & 0 & 0 & 16 & 27 & 19 & \multirow{2}{*}{0.7} & \multirow{2}{*}{10.9} & \multirow{2}{*}{0} & \multirow{2}{*}{ Confirmed } \\
\hline & freq $\%$ & 0 & 0 & 25.8 & 43.5 & 30.6 & & & & \\
\hline \multirow{2}{*}{$\begin{array}{l}\text { The sense and mentality of the mutual } \\
\text { participation and coordination }\end{array}$} & Freq & 0 & 2 & 11 & 31 & 18 & \multirow{2}{*}{0.7} & \multirow{2}{*}{10.6} & \multirow{2}{*}{0} & \multirow{2}{*}{ Confirmed } \\
\hline & freq $\%$ & 0 & 3.2 & 17.7 & 50 & 29 & & & & \\
\hline \multirow{2}{*}{ Having the authorized certificates and GMP } & Freq & 0 & 0 & 3 & 16 & 42 & \multirow{2}{*}{0.5} & \multirow{2}{*}{22.1} & \multirow{2}{*}{0} & \multirow{2}{*}{ Confirmed } \\
\hline & freq $\%$ & 0 & 0 & 4.9 & 26.2 & 68.9 & & & & \\
\hline
\end{tabular}

\section{DATA ANALYSIS}

The One-Sample T Test was also used with the 95\% confidence to examine the components' significance. According to the results, as the significance level is $P$ value $<a=0.05$, and $T$ has a positive sign, then all the components are confirmed. On the other hand, as $T$ is positive, and the Test value is considered at 3 , then the resultant components are all more than 3 (average option). The test was also repeated on the groups:

Table 12 The T-test on groups
\begin{tabular}{|l|c|c|c|}
\hline \multicolumn{1}{|c|}{ Group } & $T$ & Significance & Result \\
\hline Quality & 21.292 & 0.000 & Confirmed \\
\hline Environmental factors & 7.371 & 0.000 & Confirmed \\
\hline Flexibility & 14.956 & 0.000 & Confirmed \\
\hline Delivery & 28.654 & 0.000 & Confirmed \\
\hline Technology & 15.838 & 0.000 & Confirmed \\
\hline $\begin{array}{l}\text { Information and } \\
\text { communication systems }\end{array}$ & 16.229 & 0.000 & Confirmed \\
\hline Cost & 21.383 & 0.000 & Confirmed \\
\hline Record & 9.116 & 0.000 & Confirmed \\
\hline
\end{tabular}

According to Tab. 12, it is found that the significance of all components is confirmed. In other words, all components and groups are proper tools to evaluate variables and the research conceptual model. In addition, according to the Onesample T-test, it is found that the significance of each component/group is more than 3 (the test value) in .05 significance level. The questionnaire components are classified by two methods: Fuzzy TOPSIS and Friedman test using the SPSS software which are described below:

\section{The first method of classification: Fuzzy TOPSIS}

The Fuzzy theory is used in the uncertainty conditions which is a mathematical precise and systematic way of modelling the vague priorities [31,32]. The questionnaire is designed based on the Likert scale and the options are very high, high, moderate, low, and very low with 1 for very low and 5 for very high. The linguistic numbers provided in table 13 are used in order to use triangular fuzzy numbers and based on the studies on different papers.
Table 13 Linguistic Variables [31]

\begin{tabular}{|l|c|c|}
\hline Very low & 1 & $(0,0.1,0.2)$ \\
\hline Low & 2 & $(0.1,0.25,0.4)$ \\
\hline Moderate & 3 & $(0.3,0.5,0.7)$ \\
\hline High & 4 & $(0.6,0.75,0.9)$ \\
\hline Very high & 5 & $(0.8,0.9,1)$ \\
\hline
\end{tabular}

All questions have the positive meaning and the weights of all the questions are equal and 1. The final result of the components is presented in Tab. 14 according to the priority (from the most significance to the lowest significance).

\begin{tabular}{|c|c|c|}
\hline Question & Sub group & $C_{i}$ \\
\hline 12. in time delivery & delivery & 0.140 \\
\hline $\begin{array}{l}\text { 23. the product lower cost } \\
\text { compared to competitors }\end{array}$ & cost & 0.158 \\
\hline $\begin{array}{l}\text { 14. delivery reliability (no } \\
\text { interruption in product delivery) }\end{array}$ & delivery & 0.169 \\
\hline $\begin{array}{l}\text { 5. the authorized certificates and } \\
\text { GMP }\end{array}$ & quality & 0.185 \\
\hline $\begin{array}{l}\text { 1. Higher return rate of } \\
\text { product/raw material from } \\
\text { supplier }\end{array}$ & quality & 0.207 \\
\hline $\begin{array}{l}\text { 25. reducing additional costs } \\
\text { compared to competitors }\end{array}$ & cost & 0.215 \\
\hline $\begin{array}{l}\text { 27. the record of positive } \\
\text { performance }\end{array}$ & record & 0.227 \\
\hline 21. mutual trust & $\begin{array}{c}\text { Information and } \\
\text { communication systems }\end{array}$ & 0.237 \\
\hline 18. Easiness in relationship & $\begin{array}{c}\text { Information and } \\
\text { communication systems }\end{array}$ & 0.248 \\
\hline $\begin{array}{l}\text { 2. Higher return rate of } \\
\text { product/raw material from } \\
\text { supplier }\end{array}$ & quality & 0.248 \\
\hline $\begin{array}{l}\text { 24. Lower transition cost } \\
\text { compared to competitors }\end{array}$ & cost & 0.262 \\
\hline $\begin{array}{l}\text { 13. Suppliers' distribution } \\
\text { network quality }\end{array}$ & delivery & 0.284 \\
\hline 10. Customization & Flexibility & 0.306 \\
\hline 29. skilled human resource & record & 0.329 \\
\hline $\begin{array}{l}\text { 3. quality and continuous } \\
\text { improvement systems }\end{array}$ & quality & 0.339 \\
\hline $\begin{array}{l}\text { 4. the sense and mentality of } \\
\text { mutual participation and } \\
\text { collaboration }\end{array}$ & quality & 0.344 \\
\hline
\end{tabular}


Table 14 Prioritizing the supplier risks in the production projects based on the Fuzzy TOPSIS (continuation)

\begin{tabular}{|l|c|c|}
\hline \multicolumn{1}{|c|}{ Question } & Sub group & $C_{i}$ \\
\hline 11. service flexibility & Flexibility & 0.362 \\
\hline 26. no record of bankruptcy & record & 0.367 \\
\hline $\begin{array}{l}\text { 15. the product development } \\
\text { technology level in the supplier } \\
\text { factory }\end{array}$ & Fechnology & 0.374 \\
\hline 20. long term relationships & $\begin{array}{l}\text { Information and } \\
\text { communication systems }\end{array}$ & 0.397 \\
\hline 8. volume flexibility & Technology & 0.399 \\
\hline $\begin{array}{l}\text { 17. ability to reduce production costs } \\
\text { using the top technologies }\end{array}$ & Flexibility & 0.414 \\
\hline 19. close relationships & $\begin{array}{l}\text { Information and } \\
\text { communication systems }\end{array}$ & 0.452 \\
\hline $\begin{array}{l}\text { 9. flexibility in received product and } \\
\text { raw material diversity }\end{array}$ & $\begin{array}{l}\text { Information and } \\
\text { communication systems }\end{array}$ & 0.490 \\
\hline 22. E-commerce (IT) maturity level & Environmental & 0.498 \\
\hline $\begin{array}{l}\text { 6. observing environmental terms in } \\
\text { the supplier factory }\end{array}$ & Technology & 0.533 \\
\hline $\begin{array}{l}\text { 28. having plans to control } \\
\text { environmental factors }\end{array}$ & Environmental & 0.567 \\
\hline $\begin{array}{l}\text { 16. the ability to develop the } \\
\text { production technology in near future } \\
\text { in supplier factory }\end{array}$ & 0.597 \\
\hline $\begin{array}{l}\text { 7. waste management in the supplier } \\
\text { factory }\end{array}$ & $\begin{array}{l}\text { 30. number of agreement of supplier } \\
\text { with the multi-national companies }\end{array}$ & \\
\hline
\end{tabular}

Table 15 Prioritizing the environmental risks based on the Fuzzy TOPSIS

\begin{tabular}{|l|l|l|}
\hline \multicolumn{1}{|c|}{ Question } & \multicolumn{1}{c|}{ Sub-group } & $C_{i}$ \\
\hline 31. change in exchange rate & environmental risks & 0.156 \\
\hline 36. sanctions & environmental risks & 0.207 \\
\hline $\begin{array}{l}\text { 33. change in customs policies } \\
\text { and tariffs }\end{array}$ & environmental risks & 0.254 \\
\hline 32. change in interest rate & environmental risks & 0.326 \\
\hline $\begin{array}{l}\text { 35. country's political } \\
\text { transformation }\end{array}$ & environmental risks & 0.329 \\
\hline 37. war and terrorism & environmental risks & 0.385 \\
\hline 34. change in paid tax & environmental risks & 0.402 \\
\hline 38. natural disasters & environmental risks & 0.493 \\
\hline 39. change in consumer's taste & environmental risks & 0.680 \\
\hline
\end{tabular}

The second method of classification: Friedman Test

The second method of classification is Friedman test [33] in which, the significance level is also lower than 0.05 .

Table 16 Friedman Test for components

\begin{tabular}{|l|l|}
\hline No. of questionnaires & 61 \\
\hline Chi-square & 436.569 \\
\hline DoF & 38 \\
\hline sig & 0.000 \\
\hline
\end{tabular}

Since the significance level is also lower than 0.05 in this test $(0.000)$, the test is confirmed for the questionnaire components. The components 12 and 23 and the components 30 and 7 are the components with highest and lowest significance in this test, respectively (similar to the Fuzzy TOPSIS technique).

There is a partial difference between two methods; however, the components have relatively the same significance in both methods. Regarding the environmental risks, the question 31 is determined as the most important risk by respondents in both methods and the question 39 has the lowest importance among the environmental components.
This test was also used in order to study the group importance.

Table 17 Prioritizing the supplier risks in the production projects based on

Friedman Test

\begin{tabular}{|c|c|c|}
\hline Question & Mean Rank & Priority \\
\hline 1 & 22.89 & 8 \\
\hline 2 & 21.65 & 11 \\
\hline 3 & 18.13 & 20 \\
\hline 4 & 18.32 & 19 \\
\hline 5 & 26.73 & 3 \\
\hline 6 & 15.67 & 25 \\
\hline 7 & 13.73 & 29 \\
\hline 8 & 16.88 & 23 \\
\hline 9 & 17.47 & 21 \\
\hline 10 & 20.59 & 13 \\
\hline 11 & 17.42 & 22 \\
\hline 12 & 27.75 & 1 \\
\hline 13 & 21.22 & 12 \\
\hline 14 & 26.22 & 4 \\
\hline 15 & 20.09 & 15 \\
\hline 16 & 14.36 & 27 \\
\hline 17 & 19.77 & 16 \\
\hline 18 & 22.30 & 10 \\
\hline 19 & 15.80 & 24 \\
\hline 20 & 18.58 & 18 \\
\hline 21 & 23.52 & 7 \\
\hline 22 & 14.93 & 26 \\
\hline 23 & 27.62 & 2 \\
\hline 24 & 22.80 & 9 \\
\hline 25 & 24.84 & 5 \\
\hline 26 & 19.54 & 17 \\
\hline 27 & 23.80 & 6 \\
\hline 28 & 14.21 & 28 \\
\hline 29 & 20.26 & 14 \\
\hline 30 & 12.51 & 30 \\
\hline
\end{tabular}

Table 18 Prioritizing the environmental risks based on Friedman Test

\begin{tabular}{|c|c|c|}
\hline Question & Mean Rank & Priority \\
\hline 1 & 26.66 & 1 \\
\hline 2 & 20.80 & 2 \\
\hline 3 & 23.72 & 3 \\
\hline 4 & 18.99 & 4 \\
\hline 5 & 20.12 & 5 \\
\hline 6 & 24.07 & 6 \\
\hline 7 & 19.22 & 7 \\
\hline 8 & 15.50 & 8 \\
\hline 9 & 11.32 & 9 \\
\hline
\end{tabular}

Table 19 Friedman test for groups

\begin{tabular}{|l|l|}
\hline No. of questionnaires & 61 \\
\hline Chi-square & 111.913 \\
\hline DoF & 8 \\
\hline Sig & 0.000 \\
\hline
\end{tabular}

As the significance level is lower than .05 in this test $(0.000)$, this test is also confirmed for groups.

Table 20 Prioritizing based on Friedman test

\begin{tabular}{|l|c|c|}
\hline \multicolumn{1}{|c|}{ Group } & Mean Rank & Priority \\
\hline Quality & 5.50 & 3 \\
\hline Environmental factors & 3.30 & 7 \\
\hline Flexibility & 4.25 & 6 \\
\hline Delivery & 7.03 & 1 \\
\hline Technology & 4.39 & 5 \\
\hline Information and communication systems & 4.65 & 4 \\
\hline Cost & 6.93 & 2 \\
\hline
\end{tabular}


As can be seen, the most important group for the supplier selection is the delivery factors group (including the in time delivery, distribution network quality, and delivery reliability) and the least important group is the environmental issues in the supplier factory.

\section{CONCLUSION}

The present study aimed to provide a supplier selection model emphasizing the project risk management in drug production in the country's pharmaceutical industry utilizing the Fuzzy TOPSIS technique as well as the Friedman Test to prioritize groups. According to the priorities obtained in the Fuzzy TOPSIS technique and the Friedman Test, the data in $20 \%$ top of the means were eliminated (due to elimination of the least important data).

Table 21 The means based on group priority in supplier selection in pharmaceutical industry

\begin{tabular}{|c|c|c|}
\hline Group & Component & $\begin{array}{c}\text { Mean } \\
\% \\
\%\end{array}$ \\
\hline \multirow{3}{*}{ delivery } & 12. in time delivery & 40.96 \\
\hline & 13. suppliers' distribution network quality & 83.09 \\
\hline & $\begin{array}{l}\text { 14. delivery reliability (no interruption in } \\
\text { product delivery) }\end{array}$ & 49.44 \\
\hline \multirow{3}{*}{ cost } & $\begin{array}{l}\text { 23. the product lower cost compared to } \\
\text { competitors }\end{array}$ & 46.23 \\
\hline & $\begin{array}{l}\text { 24. lower transition cost compared to } \\
\text { competitors }\end{array}$ & 76.65 \\
\hline & $\begin{array}{l}\text { 25. reducing additional costs compared to } \\
\text { competitors }\end{array}$ & 62.90 \\
\hline \multirow{5}{*}{ quality } & $\begin{array}{l}\text { 1. Higher return rate of product/raw } \\
\text { material from supplier }\end{array}$ & 60.56 \\
\hline & $\begin{array}{l}\text { 2. proper quality of the supplier support } \\
\text { system }\end{array}$ & 72.56 \\
\hline & $\begin{array}{l}\text { 3. quality and continuous improvement } \\
\text { systems }\end{array}$ & 99.18 \\
\hline & $\begin{array}{l}\text { 4. the sense and mentality of mutual } \\
\text { participation and collaboration }\end{array}$ & 100.64 \\
\hline & 5. the authorized certificates and GMP & 54.13 \\
\hline \multirow{5}{*}{$\begin{array}{l}\text { Information } \\
\text { and } \\
\text { communication } \\
\text { systems }\end{array}$} & 18. easiness in relationships & 72.56 \\
\hline & 19. close relationships & 132.24 \\
\hline & 20. long term relationships & 116.15 \\
\hline & 21. mutual trust & 69.34 \\
\hline & 22. e-commerce maturity level & 143.36 \\
\hline \multirow{4}{*}{ Flexibility } & 10. Customization & 89.53 \\
\hline & 11. service flexibility & 105.91 \\
\hline & 8. volume flexibility & 114.39 \\
\hline & $\begin{array}{l}\text { 9. flexibility in received product and raw } \\
\text { material diversity }\end{array}$ & 121.12 \\
\hline \multirow{5}{*}{ record } & 26. no record of bankruptcy & 107.37 \\
\hline & 27. the record of positive performance & 66.41 \\
\hline & $\begin{array}{l}\text { 28. having plans to control environmental } \\
\text { factors }\end{array}$ & 150.67 \\
\hline & 29. skilled human resource & 96.26 \\
\hline & $\begin{array}{l}\text { 30. number of agreement of supplier with } \\
\text { the multi-national companies }\end{array}$ & 174.66 \\
\hline \multirow{3}{*}{ technology } & $\begin{array}{l}\text { 15. the product development technology } \\
\text { level in the supplier factory }\end{array}$ & 109.42 \\
\hline & $\begin{array}{l}\text { 16. the ability to develop the production } \\
\text { technology in near future in supplier }\end{array}$ & 155.94 \\
\hline & $\begin{array}{l}\text { 17. ability to reduce production costs using } \\
\text { the top technologies }\end{array}$ & 116.73 \\
\hline \multirow{2}{*}{ Environmental } & $\begin{array}{l}\text { 6. observing environmental terms in the } \\
\text { supplier factory }\end{array}$ & 145.70 \\
\hline & $\begin{array}{l}\text { 7. waste management in the supplier } \\
\text { factory }\end{array}$ & 165.89 \\
\hline
\end{tabular}

As can be seen in the table of $C_{i}$ means, the e-commerce maturity level, having plans to control the environmental factors, the agreements of the intended supplier with the multi-national company, the ability to develop the technology for supplier factory are the importance factors in suppler selection in pharmaceutical industry. It is better to eliminate them from the top supplier selection indicators in the country's pharmaceutical industry. Based on the table of the $C_{i}$ means in the environmental risks, "change in the consumers' tastes" has no effect on the country's pharmaceutical industry or in other words, it has a low value in managing the environmental risks in the country's pharmaceutical industry in terms of the experts. The following points should be considered in order to reduce the supplier risk in the drug production projects.

The change in the consumer's taste is not an evaluable factor in the pharmaceutical industry.

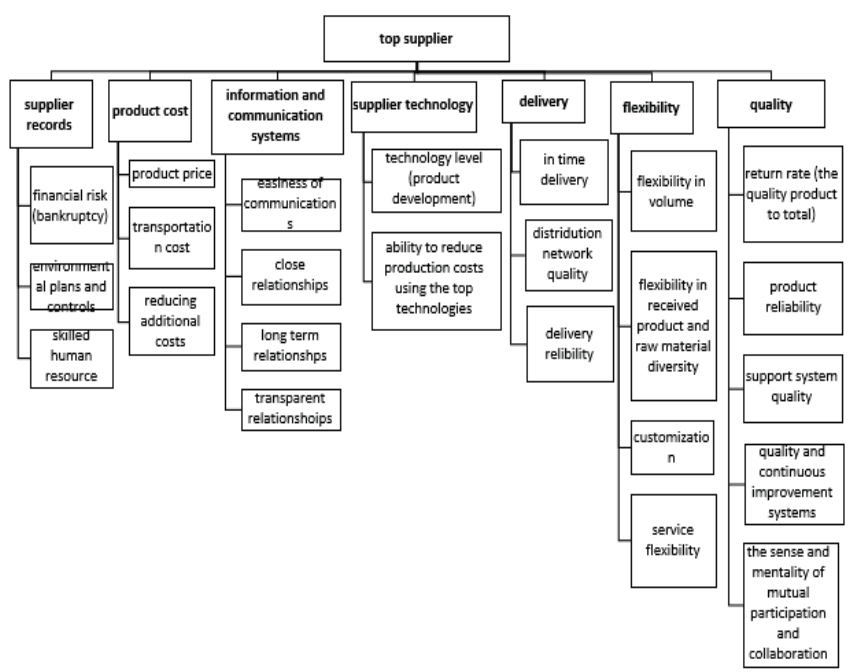

Figure 6 The final model of top supplier selection in the pharmaceutical industry

The priority in the supplier selection is related to ones who meet the delivery and cost indicators to the best possible way.

For this purpose, they should have in-time delivery, a distribution network with proper quality, and not interrupt the supply of the raw material/product suddenly.

On the other hand, their prime price should be lower than the competitors' of the same quality. Having the authorized certificates, including the Ministry of Health certificates and GMP etc., is in priority of decisions; however, the Ministry of Health permission is needed with regard to procuring the pharmaceutical raw material.

Flexibility in volume and services as well as the product diversity do not matter in the pharmaceutical industry because the pharmaceutical raw materials follow special standards and terms that changing them is not desirable for the buyer.

In line with the supplier's selection desirable terms, the environmental risks should not be ignored. Accordingly, the supplier with a plan for economical-political risks is in priority. 
The change in the interest rate, sanctions, change in the customs tariff, etc., can result in the supplier failure and consequently, product supply interruption if these measures are unplanned.

The following suggestions can be considered in this regard for the future research:

The present research perspective to define the risk events is a project risk management and a customer-oriented view and it also considers the events resulting in the customer dissatisfaction - the producer's view in this research - to the supplier's activities as the risk events.

However, it should not be ignored that the customers' expectations and views are not the only important issue but the other groups' views including shareholders, employees, suppliers, and even society is important.

Hence, the more holistic view can consider these views in defining the risk events and build a model to incorporate these views.

For example, the risk drivers should also be defined and measured in this regard considering the shareholders' and company owners' views.

The statistical population in this study consisted of the pharmaceutical industry supply chain including Tamin pharmaceutical investment, Alborz investment, and Shafadarou Company.

The use of a broader statistical population like the whole pharmaceutical industry or incorporating other main holdings can provide a bigger sample and hence, more generalizable results.

The risks identified in this research can be ranked utilizing the project management methods based on the PMBOK standard.

\section{REFERENCES}

[1] Oke, A. \& Gopalakrishnan, M. (2009). Managing disruptions in supply chains. Production Economics, (118), 168-174. https://doi.org/10.1016/j.jpe.2008.08.045

[2] Marty, J. (2008). Supplier Selection Using Fuzzy Network Analysis Research Technique. Journal of the Faculty of Engineering, 1(1), 6-7.

[3] Khavarpour, M. \& Hosseinpour, S. (2009). We are currently guessing new planning. You National Conference on Internal Capacity Promotion, 8-16. https://doi.org/10.1177/1757975908100746

[4] Adel Azar (2004). Management Research Methodology: A Comprehensive Approach. Tehran: 156-190.

[5] Sadeghi, A., Azar, A., Valmohammadi Ch., \& Alirezaei, A. (2020). Designing a product-service supply chain performance evaluation model in the home appliance industry using factor analysis and fuzzy neural network. Production and Operations Management, 10(2), 83-123.

[6] Amiri, A. \& Momeni, M. (2014). Statistical analysis was performed using SPSS. Tehran: The New Book, 16-187.

[7] Bani Asadi, P., Hermiz, R., \& Mason-Jones, R. (2005). Information flow in automative supply chains- identifying and learning to overcome barriers to change. Industrial management \& data system, 103(7), 491-502.

https://doi.org/10.1108/02635570310489197
[8] Sayadi, R. \& Tallur, S. (2011). Perspectives on risk management in supply chains. Journal of Operations Management 27(1), 114-118. https://doi.org/10.1016/j.jom.2009.02.001

[9] Alvarado, Y. \& Kotzab, H. (2001). The integration of logistics and marketing industrial marketing management. Supply chain management, 183-198. https://doi.org/10.1016/S0019-8501(00)00142-5

[10] Chopra, S. \& Sodhi, M. S. (2004). Managing risk to avoid supply chain breakdown. MIT Sloan Management Review 46(1), 53-62.

[11] Brindley, C. \& Ritchie B. (2004). Supply Chain Risk. Ashgate Publishing, 60-75.

[12] Jugdev, K. \& Mathur, G. (2006). Project management elements as strategic assets: preliminary findings. Management Research News, 604-617. https://doi.org/10.1108/01409170610712317

[13] Jugdev, K., Mathur, G. (2006). Project management elements as strategic assets: preliminary findings. Management Research News, 29(10), 604-617. https://doi.org/10.1108/01409170610712317

[14] Childerhouse, P., Hermiz, R., \& Mason-Jones, R. (2003). Information flow in automotive supply chains- identifying and learning to overcome barriers to change. Industrial management \& data system, 103(7), 491-502. https://doi.org/10.1108/02635570310489197

[15] Cucchiella, F. \& Gastaldi, M. (2006). Risk management: a real option approach. Journal of Manufacturing Technology Management, 17(6), 700-720. https://doi.org/10.1108/17410380610678756

[16] Morkabati, S., Lasch, R., \& Tamaschke, R. (3, 2009). Supplier development with benchmarking as part of a comprehensive supplier risk management framework. International journal of operations \& production management, 29, 241-267. https://doi.org/10.1108/01443570910938989

[17] Norrman, A. \& Lindroth, R. (2004). Categorization of supply chain risk and risk management. In supply chain risk management. In C. Brindley (Ed.): Ashgate Publishing Limited.

[18] Chan, F. T. S. \& Qi, H. J. (2003). Feasibility of performance measurement system for supply. Integrated Manufacturing Systems, 14(3), 179-190. https://doi.org/10.1108/09576060310463145

[19] Tang, C. (2006). Robust strategies for mitigating supply chain disruptions. International Journal of Logistics: research and application, 9, 33-45. https://doi.org/10.1080/13675560500405584

[20] Jain, J., Dangayach, G., Agarwal, G, \& Banerjee, S. (2010). Management: Literature Review and Some Issues. Journal of Studies on Manufacturing, 1(1), 11-25.

[21] Wu, T., Blackhurst, J., \& Chidambaram, V. (2006). A model for inbound risk analysis. Computers in Industry, 57, 350-365. https://doi.org/10.1016/j.compind.2005.11.001

[22] Duncan, R. (1972). Characteristics of organizational environments and perceived environmental uncertainty. Administrative Science Quarterly, 17(3), 56-67. https://doi.org/10.2307/2392145

[23] Lee, A. (2019). A fuzzy supplier selection model with the consideration of benefits, opportunities, costs and risks. Expert Systems with Applications, 36, 2879-2893. https://doi.org/10.1016/j.eswa.2008.01.045

[24] Zsidisin G., Ellram L., Carter J., \& Cavinato J. (2004). An analysis of supply risk assessment techniques. International Journal of Physical Distribution \& Logistics Management, 34(5), 397-413. https://doi.org/10.1108/09600030410545445 
[25] Finch, P. (2004). Risk management. Supply Chain Management, 9(2), 183-196. https://doi.org/10.1108/13598540410527079

[26] Hakonsen, H. \& Horn, A. M. (2009). Price control as a strategy for pharmaceutical cost. Health Policy, 277-285. https://doi.org/10.1016/j.healthpol.2008.09.018

[27] Harland, C., Brenchley R., \& Walker H. (2003). Risk in supply networks. Journal of Purchasing and Supply Management, 9(2), 51-62. https://doi.org/10.1016/S1478-4092(03)00004-9

[28] Johnson, E. (2001). Learning from toys: Lessons in managing supply chain risk from the toy industry. California Management Review, 43, 106-130. https://doi.org/10.2307/41166091

[29] Jones, A. (2005). An Introduction to Factor Analysis of Information Risk (FAIR). Retrieved from Risk Management Insight: http://www.riskmanagementinsight.com

[30] Miles, R. S. (1978). Organization Strategy, Structure, and Process. New York: McGraw-Hill, 160-180.

[31] Nienhaus, J., Ziegenbein, A., \& Schoensleben, P. (2004). How human behaviour amplifies the bullwhip effect. A study based on the beer distribution game online. Production Planning \& Control / The Management of Operations, 17(16), 113-130. https://doi.org/10.1080/09537280600866587

[32] Wang, L., Kong, L., Wu, F., Bai, Y., \& Burton, R. (2015). Preventing chronic diseases in China. The Lancet, 1821-1824. https://doi.org/10.1016/S0140-6736(05)67344-8

[33] Yu X., Li C., Shi, Y., \& Yu, M. (2010). Pharmaceutical supply chain in China: Current issues and implications for health system reform. Health Policy, 97(1), 8-15. https://doi.org/10.1016/j.healthpol.2010.02.010

\section{Authors' contacts:}

Malek Mohammad Sabbaghi, MsC in Industrial Engineering Institute of Al-Ghadir,

Chair of the Board in Rasa Pharmaceutical Development Company,

Vali Asr Ave. Moghadas Ardebili Streets, Alleys Tofigh, No. 3

Tehran, Iran

Ahmad Allahyari, $\mathrm{PhD}$ in Industrial Engineering, (Corresponding author)

Islamic Azad University, South Tehran Branch,

No. 223, ZIP area 11, Azarshahr Street, North Iranshahr Street,

Karimkhan-e-Zand Avenue, Tehran, Iran

E-mail: dr.ahmad.alahyari@gmail.com 